\title{
RESEARCH AND EXHIBITION IN A MUSEUM
}

\author{
BY \\ P. J. VAN DER FEEN \\ Zoological Museum, Amsterdam
}

If you ask the layman: "What is a museum ?", he will answer. "A museum is a display of objects, that have an aesthetic value or scientific interest; the scope of a museum is to improve the taste of the visitor, is to give him, by visual means, aesthetic or intellectual enjoyment, to satisfy his curiosity, to show him the true and real things (a classic sculpture, an Indian weapon or a deepsea fish) instead of a documentary film, a radio report, or the descriptions and pictures in his books and magazines."

If an architect is in charge of designing a museum, he will see to it that the wallcases and the free-standing objects receive the right light and that the public and the conditioned air can circulate freely. He will design an entrance hall, an exhibition gallery, a director's room, and, perhaps, in the basement or on the top-floor a store-room for articles not on display ${ }^{1}$ ).

This conception of a museum as an exhibition gallery, a thing of luxury rather than of practical value, is still widely held. This conception was quite right in the middle of the Igth century. It is founded in the origin of the public museum: the private gallery of curiosities and fine art objects.

In two regards the modern museum differs from the former private gallery. The latter had only to satisfy the wishes of the private owner, who was, as a rule, a real connoisseur. The museum, however, has to reckon with always new and unspecialized visitors. Secondly a modern museum keeper has a quite other task than a private collector a century ago.

The private owner was proud of the richness of his collection. He liked to show it to visitors. If his rooms were over-filled, it did not disturb his pleasure, for, looking at one of his well-known possessions, he was not

I) E.g. in the 'Encyclopaedia Britannica' (Chicago, London, Toronto, 1945), Vol. 15, p. 990, at the entry 'Museum Architecture', we read: "Both art and scientific museums "have the primary purpose of displaying collections of objects; consequently, certain "features of architectural planning are common to both. Essentially, the plan of each "must provide for the free and comfortable circulation of the public, an easy access "to the various sections of the building and a coherent arrangement of rooms and "galleries." 
distracted by the surrounding ones. If he desired, he could take any single piece in his hands to consider it separately.

When the public museum was young and contained relatively few objects, it could show all its possessions to the public. The more its collections increased in number of objects, the more the walls and cases were filled. Soon an average visitor saw nothing but rows and rows of paintings or coins or shells, his attention was not drawn to anything apart. In less than an hour he was exhausted and could assimilate nothing more.

Gradually the collections of a museum increased immensely. It was wholly impossible to exhibit all of them. What could not find a place in the gallery was stored in improvised cabinets in the basement or in the attic. The rooms of the director and keepers were crowded with books, drawings and objects in preparation or in study.

Meanwhile, next to the exhibition, other functions of a museum developed.

Collectors, teachers, students, merchants and travellers all came to the museum with their questions, some important only for the inquirer himself, some of high scientific or economical interest. Thus the information service became more and more extensive.

The first task of a modern museum keeper is to label every acquisition and to register all data available about the origin of the object. At the same time it is classified at least provisionally and is inscribed in a systematic catalogue. When this has been done and when the object has undergone the due preparation to prevent decay, it is available for research. To give full profit in science, the possessions of a museum ought to be published, in the form of short records in a catalogue, or in extensive monographs or in any other form. Once published the material is at the disposal not only of the museum staff itself, but also of the scientists all over the world.

In all this work we must bear in mind that description and classification have only partly a scientific aim in themselves. They are, however, indispensable steps in making material of use for conclusions and experiments either of practical or of purely scientific importance.

There is another reason why, especially in museums of natural history, the storage place has an increasing importance. In the period when individual differences between the organisms of the same species were considered of no importance for science, a museum could suffice by collecting one specimen (or only few specimens) of each species. Duplicates could be exchanged with other collections. In biology nowadays we are studying individuals, as representatives of populations. We study them with statistical methods, and we try to arrange them in species and other taxa of higher or lower range. The more individuals we have at hand, the better it is. Now we find it difficult to say what is a duplicate. It is evident we cannot show all these statistical series to the public. I suppose in archaeology and ethnology the situation is much the same as in biology. 
Besides the general stored collection and the exhibition there should be collections for younger students and serious amateurs. Although these persons lack the full responsability and ability of a specialised investigator, they should be enabled to take specimens in hand and to compare them with the aid of handbooks and monographs.

To put specimens in a good state of conservation at the disposal of scientific workers, that is now the first task of a museum. The old definition "a museum is a show-gallery" is to be replaced now by another one: "A museum is a store of materials of scientific, historic or aesthetic value. These materialis are preserved, studied and published. Only part of them are exhibited for the public."

The old rule "every good object is shown to the public", is no more valid. We say now „every object of authenticated origin ought to be published and is shown on demand to any serious student." I cannot too much emphasize it : a museum should store up all its possessions and then make a choice for the exhibition. This exhibition should not be a mere display of the finest objects from the collection, but has to demonstrate a distinct idea to the public.

It is a general experience that even the best exhibition in a museum loses its freshness in a few years. Therefore the displays must be changed often. Even in the case the same specimens (e.g. the most famous pieces of the museum) are to be exhibited again, they should be placed every time in a new combination, according to new results and new ideas.

I am not speaking here about the aesthetic function of a museum. In some museums this function is primary. Not a single museum can neglect it in its exhibition gallery.

When a new museum is to be built, or a new museum is to be arranged in an existing building that has been erected for another purpose, the question arises: how many cubic metres ought to be fixed for storage cabinets, laboratories and library, how. many for the exhibition gallery? To solve this problem, we can ask "what can really be seen and understood by an interested and intelligent visitor in one or two visits to the museum?" It is too optimistic to suppose that, on the average, a visitor spends one minute on any object we have so carefully placed and so clearly explained on the label. But if he spends less than half a minute he rarely can see and read something serious. Let us say he can perceive about hundred objects in an hour. So, if we exhibit a maximum of thousand single specimens, each visitor has plenty of opportunity, in a visit of one or two hours, to choose what he wishes to see, and to return another time to study other parts of the exhibit.

In the display collection the attention of a visitor ought to be drawn to each single object without being distracted by surrounding specimens. To accomplish this and to give enough room to the public, I estimate that each specimen in the exhibition (should it be an elephant or a shell) takes hundred times as many cubic units as the same specimen in the cabinet. 
In biological, geological and archaeological museums surely only one of thousand specimens can be exhibited during a certain period. These 1000 specimens take 1000 A space, being A a certain amount of cubic units. The one displayed specimen takes temporarily $100 \mathrm{~A}$. Reasoning in this way we have to fix for the storage cabinets, in cubic metres, ten times as much space as for the exhibition galleries.

In a newly established museum the working rooms and the show galleries can be in use from the first day on. But of the store cabinets a great deal must be reserved for the future. For it is in the very nature of museum collections to increase, and in a flourishing museum with active keepers and much visitors to increase at a fast rate. An increase of $100 \%$ in a human generation is not excessive.

In addition to stored collection and exhibition gallery there must be working rooms for scientific research, for the administration and archives, for various technical purpose (preparation, expedition, photography, drawing, heating etc.) and for the library.

A museum cannot work without the most direct aid of a very extensive, and at the same time highly specialized, library. The library can have its own function as a centre of information for the public. Yet in the whole management of the library, including the arrangement of books, periodicals and reprints, the catalogue apparatus and the acquisition of new items, there ought to be the closest collaboration between the museum and the library.

A museum without an exhibition gallery can do very good and important scientific work. The display takes time and money and room, but it is an indispensable part of the social task of a museum, and in the long run it pays in the form of goodwill and gifts to the institute.

The principles sketched above lead to the conclusion that it is not right to found a show inuseum without a corresponding scientific department. The displays can only be an often renewed selection from the storage collections, and a reflection of some modern or classic human thoughts. To take the scientific research from a museum is to take its heart and its life.

Under the direction of Dr. L. F. DE BeAufort, the Zoological Museum at Amsterdam, in the old and scattered buildings, has maintained an equilibrium between the different functions of a museum. I hope it will do so in the future also. 